\title{
Effect of preharvest application of chemicals and plant growth regulators on physical parameters and shelf-life of custard apple (Annona squamosa L.)
}

\author{
A. A. BAGUL* AND M. M. MASU \\ Department of Horticulture, B. A. College of Agriculture, Anand Agricultural University, \\ ANAND (GUJARAT) INDIA (Email : bagulanand123@gmail.com)
}

\begin{abstract}
The three varieties of custard apple were subjected to various preharvest chemicals and plant growth regulators treatments, viz., $\mathrm{CaCl}_{2} @ 2 \%, \mathrm{KNO}_{3} @ 2 \%, \mathrm{GA}_{3} @ 50 \mathrm{mg} / \mathrm{l}$, NAA @ $50 \mathrm{mg} / \mathrm{l}$ and no spray. Then mature, uniformed sizes fruit were harvested and observation were recorded under ambient storage condition. Balanagar recorded maximum fruit weight $(180.32 \mathrm{~g})$, volume $(109.42 \mathrm{cc})$ and pulp weight per fruit $(90.52 \mathrm{~g})$ while minimum peel weight per fruit $(53.87 \mathrm{~g})$ and seed weight per fruit $(10.43$ g) recorded in Local variety at harvest. GA @ $@ 50 \mathrm{mg} / \mathrm{l}$ were found to best since they have maximum fruit weight $(159.60 \mathrm{~g})$, volume $(96.85 \mathrm{cc})$ and pulp weight per fruit $(79.54 \mathrm{~g})$ at harvest. In case of fruit diameter $(7.39 \mathrm{~cm}, 7.09 \mathrm{~cm})$ in both factors were recorded maximum at $3^{\text {rd }}$ day of storage. $\mathrm{CaCl}_{2} @ 2 \%$ recorded minimum PLW $\left(23.54 \%\right.$ at $6^{\text {th }}$ day) and spoilage percentage $(32.22 \%)$ and maximum fruit firmness $\left(0.25 \mathrm{~kg} / \mathrm{cm}^{2}\right.$ at $6^{\text {th }}$ day), shelf-life of fruits (7.25 days) and marketable fruit percentage $(67.78 \%)$ during storage. Thus, it can be inferred from the study that Balanagar variety and GA $@ 50 \mathrm{mg} / \mathrm{l}$ rated as most acceptable and superior, over all the other treatments in term of physical parameters and in term of quality and shelf-life $\mathrm{CaCl}_{2} @ 2 \%$ treatment observed during ambient storage.
\end{abstract}

Key Words : Calcium chloride, Potassium nitrate, NAA, GA 3 , Physical parameters, shelf-life

View Point Article : Bagul, A.A. and Masu, M.M. (2017). Effect of preharvest application of chemicals and plant growth regulators on physical parameters and shelf-life of custard apple (Annona squamosa L.). Internat. J. agric. Sci., 13 (2) : 371-377, DOI:10.15740/HAS/ IJAS/13.2/371-377.

Article History : Received : 03.02.2017; Revised : 02.05.2017; Accepted : 17.05.2017

\footnotetext{
* Author for correspondence:
} 